\title{
PARTICULAR QUALITIES OF THE PROTEOLYTIC SYSTEM IN PATIENTS WITH TUBERCULOSIS DEPENDING ON THE SENSITIVITY OF THE PATHOGEN
}

\author{
Igor D. Duzhyi, Halyna P. Oleshchenko, Ivan A. Hnatenko, Stanislav 0. Holubnychyi \\ SUMY STATE UNIVERSITY, SUMY, UKRAINE
}

\begin{abstract}
The aim: Studying the features of the proteolytic system in patients with tuberculosis depending on the sensitivity of the pathogen.

Materials and methods: In the course of the research we studied the level of elastase in the blood of 111 patients. The first group consisted of 66 (59.5\%) people with pulmonary tuberculosis ( 39 were sensitive to antibacterial drugs, 27 were resistant). The second group included $13(11.7 \%)$ patients with tuberculous pleurisy. The third group consisted of 32 (28.8\%) patients with dual localization of the process (pulmonary tuberculosis and pleural tuberculosis).

Results: The level of neutrophil elastase in patients with tuberculous pleurisy $(253.2 \mathrm{nmol} / \mathrm{min} \cdot \mathrm{ml})$ was 2.2 times higher than in patients with sensitive pulmonary tuberculosis $(110.1 \mathrm{nmol} / \mathrm{min} \bullet \mathrm{ml})$ and higher than in patients with resistant pulmonary tuberculosis 3.0 times. In combined pulmonary and pleural tuberculosis (third group) the level of elastase was 1.6 times higher than in pulmonary tuberculosis $(176.9 \mathrm{nmol} / \mathrm{min} \bullet \mathrm{ml}))(p<0.01)$, but lower than in pleurisy in 1,4 times. In sensitive combined tuberculosis (lungs and pleura) the level of NE was 1.5 times higher than in patients of subgroup $1 \mathrm{a}(\mathrm{p}<0.01)$ and 1.4 times lower than in patients with tuberculous pleurisy $(\mathrm{p}<0.01)$. Conclusions: The highest level of elastase in tuberculous pleurisy can be explained by its increased production, contributes to increased "permeability" of the pleural sheets and the accumulation of pleural effusion. In resistant forms of tuberculosis, the immune response in the form of the activity of the proteolytic system, which is lower than in sensitive forms, can be explained by the exhaustion of the immune system under the influence of aggressive tuberculosis. The above can be associated with both the weakening of the patient's body and the aggressiveness of the pathogen.
\end{abstract}

KEY WORDS: elastase, pulmonary tuberculosis, pleural tuberculosis

Wiad Lek. 2021;74(1):94-97

\section{INTRODUCTION}

Despite the fact that tuberculosis is a curable disease, it is one of the ten causes of death in the world [1]. There was a decrease in the incidence of tuberculosis in Ukraine, in 2019 (from 62.3 to 60.1 per 100 thousand of the population) and mortality (from 9.4 to 8.8 per 100 thousand of the population) from this disease. At the same time, the incidence of children increased by $1.1 \%$, and the incidence of adolescents - by 5.3\% [2]. At the same time, the rate of increasing the effectiveness of treatment of TB patients in Ukraine is insufficient to achieve the WHO target (by 2025 there should be $90 \%$ of patients who have successful treatment). Among patients with sensitive tuberculosis, about $77 \%$ had effective treatment. Only $49 \%$ of patients with multidrug-resistant tuberculosis (MDR-TB) had a satisfactory treatment outcome. Only $37 \%$ of patients with extended resistance (XDR-TB) were successfully cured [1].

The authors had a research involving 796 patients with tuberculosis. It was found that the main barriers to tuberculosis treatment in Ukraine encompass structural barriers associated with the organization of the health care system and the unregulated regulatory framework, barriers at the level of anti-tuberculosis institutions and the general route of the patient between different branches of health care, gaps in interaction between health workers and patients, individual factors, including social, economic and psychological consequences of treatment for the patient [1].

However, there is insufficient data on the pathogenesis of tuberculosis, depending on the sensitivity of the pathogen and the characteristics of the proteolytic system.

\section{THE AIM}

Studying the features of the proteolytic system in patients with tuberculosis depending on the sensitivity of the pathogen.

\section{MATERIALS AND METHODS}

In the study, we examined 111 patients who were divided into three groups. The first group consisted of 66 (59.5\%) people with pulmonary tuberculosis (PTB) - (Table I). The second group included $13(11.7 \%)$ patients with tuberculous pleurisy (PLTB). The third group consisted of $32(28.8 \%)$ patients with dual localization of the process (pulmonary tuberculosis and pleural tuberculosis) - (PTBPLTB). The main last group consisted of 23 healthy individ- 
Table I. Distribution of examined patients according to the sensitivity of the pathogen

\begin{tabular}{cccccccc}
\hline \multirow{2}{*}{ Group patients } & \multicolumn{2}{c}{ Sensitive } & \multicolumn{2}{c}{ Resistant } & \multicolumn{3}{c}{ Total } \\
\cline { 2 - 7 } & quantity & $\%$ & quantity & q & quantity & 66 & 59,5 \\
\hline The first & 39 & 59,1 & 27 & 40,9 & 13 & 11,7 \\
\hline The second & 13 & 100,0 & - & 10 & 31,2 & 32 & 28,8 \\
\hline The third & 22 & 68,8 & $\mathbf{3 7}$ & $\mathbf{3 3 , 3}$ & $\mathbf{1 1 1}$ & $\mathbf{1 0 0 , 0}$ \\
\hline Total & $\mathbf{7 4}$ & $\mathbf{6 6 , 7}$ &
\end{tabular}

Table II. The level of neutrophil elastase in patients of the first group

\begin{tabular}{|c|c|c|c|c|c|}
\hline \multirow[b]{2}{*}{ Indicator } & \multicolumn{5}{|c|}{ Groups of patients } \\
\hline & \multicolumn{2}{|c|}{ 1a group $(n=39)$} & \multicolumn{2}{|c|}{16 group $(n=27)$} & $\begin{array}{l}\text { Control group \& } \\
\text { (relatively healthy } \\
\text { individuals) } \\
(n=23)\end{array}$ \\
\hline \multirow{2}{*}{$\begin{array}{l}\text { Neutrophil elastase, } \\
\mathrm{nmol} / \mathrm{min} \cdot \mathrm{ml}\end{array}$} & $\begin{array}{c}\text { Fluctuations of } \\
\text { values }\end{array}$ & Average value & $\begin{array}{c}\text { Fluctuations of } \\
\text { values }\end{array}$ & Average value & \multirow[t]{2}{*}{75,0} \\
\hline & $35,2-215,1$ & $110,1 \pm 11,8^{*, \#}$ & $34,6-163,1$ & $78,4 \pm 9,2^{*}$ & \\
\hline
\end{tabular}

Note:

* - statistically confirmed differences between the indicators of patients of groups I and II $(p<0,05)$;

$\#$ - statistically confirmed differences between the indicators of the studied patients and the control group $(p<0,01)$;

$\&$ - according to previous studies [4].

Table III. The level of neutrophil elastase in patients of the second group

\begin{tabular}{|c|c|c|c|}
\hline \multirow[t]{2}{*}{ Indicator } & \multicolumn{2}{|c|}{$\begin{array}{l}\text { Patients with pleurisy } \\
\qquad(n=13)\end{array}$} & \multirow{2}{*}{$\begin{array}{l}\text { Control group } \\
(n=23)\end{array}$} \\
\hline & Range & Average value & \\
\hline Neutrophil elastase, $\mathrm{nmol} / \mathrm{min} \cdot \mathrm{ml}$ & $144,7-350,5$ & $253,2 \pm 16,7^{*}$ & 75,0 \\
\hline
\end{tabular}

* - statistically confirmed differences between the indicators of the study of patients and the control group $(p<0,01)$.

uals who had no lung or pleural disease at the time of the examination and had not been ill in the past. Among the examined control group there were 11 women and 12 men.

When studying the sensitivity of the mycrobacterium tuberculosis (MBT) to antibacterial drugs, it was found that out of 39 (59.1\%) people on PTB had preserved sensitivity of mycobacteria to first-line drugs. These patients were assigned to subgroup 1a. The other 27 (40.9\%) patients had MDR-TB, that is, resistant to the two main first-line anti-TB drugs: isoniazid and rifampicin. These patients were assigned to subgroup $1 \mathrm{~b}$. Among patients of subgroup $1 \mathrm{~b}$, in addition to the MBT resistance to rifampicin and isoniazid, resistance to ethambutol was found in 17 (63.0\%) patients, to pyrazinamide in $13(48.1 \%)$ patients, and in all $100.0 \%$ of patients to streptomycin. In addition, resistance to kanamycin, capreomycin and amikacin was found in 4 (14.8\%) patients, 7 (25.9\%) and 17 (63.0\%), respectively. Resistance to levofloxacin was stated in 7 (25.9\%) patients, to ofloxacin - in 6 (22.2\%) and to moxifloxacin in 7 (25.9\%) subjects. Thus, in 7 patients, in addition to MBT resistance to rifampicin and isoniazid, a combination with one of the injectable drugs and one of the fluoroquinolones was established. So, the expanded resistance of MBT to antibacterial drugs in patients of the first group occurred in $25.9 \%$ of those studied.
In the second group, all $13(100.0 \%)$ patients were diagnosed with pleural TB with preserved sensitivity to the first-line drugs (by the genetic molecular method using the GeneXpert apparatus).

Among patients of the third group (PTB-PLTB) patients with pulmonary and pleural tuberculosis sensitive to anti-tuberculosis drugs predominated - 22 (68.8\%), which were designated as subgroup 3a. There were 10 patients (31.2\%) with resistant tuberculosis, which were assigned to subgroup $3 \mathrm{~b}$. In this subgroup (3b) in addition to resistance to isoniazid and rifampicin in 7 (70.0\%) there was resistance to ethambutol, in $9(90.0 \%)$ - to streptomycin, in $2(20.0 \%)$ - to pyrazinamide, $1(10.0 \%)$ - to capreomycin, kanamycin, ofloxacin moxifloxacin and ethionamide. Extended resistance occurred in $2(20.0 \%)$ people.

In general, among the studied patients of all groups, tuberculosis sensitive to antibacterial drugs was stated in $74(66.7 \%)$ patients, resistant - in 37 (33.3\%) people.

The study of the proteolytic system was carried out by determining the activity of neutrophil elastase in the blood serum of patients by the spectrophotometric method, preliminarily freeing it from the complex with a proteinase inhibitor using Tris-HCl buffer. N-BOC-L-Alanine p-nitrophenyl ester was used as a substrate according to a known technique [3]. 
Table IV. The level of neutrophil elastase in patients of the third group

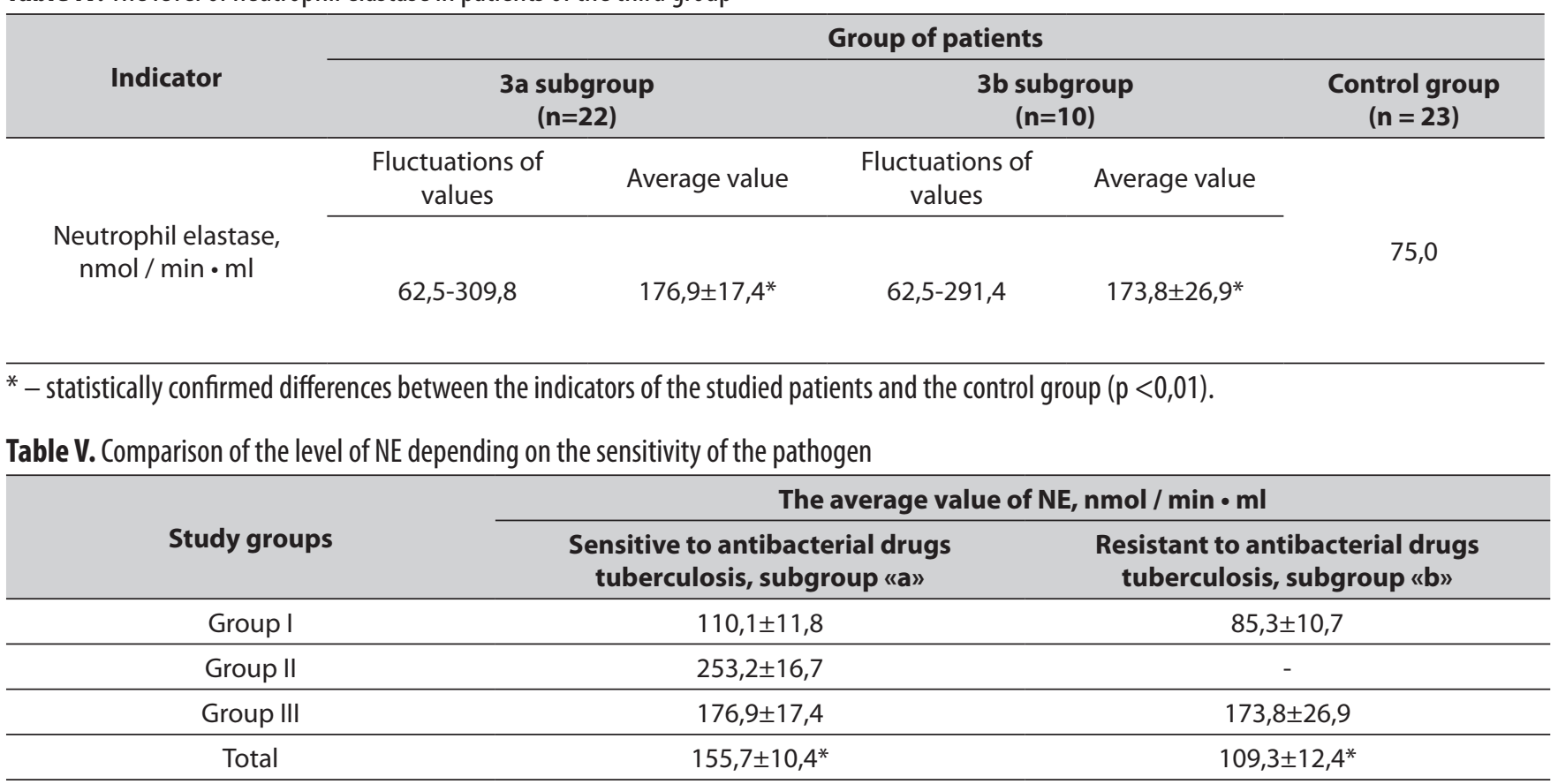

* - statistically confirmed differences between the indicators of the studied patients $(p<0,01)$.

This research was approved by the Ethics Committee of Sumy State University, Sumy, Ukraine (Protocol № 2, 03.11.2020). Research was conducted keeping to the main issues of the Convention of the Council of Europe on $\mathrm{Hu}-$ man Rights and Biomedicine of Declaration of Helsinki of the World Medical Association on the ethical principles of conducting medical research involving human beings (1975, with further amendments, including version of 2000) and Order of Ukrainian Ministry of Health № 690 on 23.09.2009.

Statistical processing of the material was carried out using licensed software products included in the Microsoft Office Home \& Business 2016 package (license X20-3434401) on a personal computer Everest in Excel program by the method of variation statistics using the Student's test. The difference in indicators was considered reliable at $\mathrm{p}<0.05$.

\section{RESULTS AND DISCUSSION}

We compared the level of neutrophil elastase (NE) in patients of both subgroups with the level of NE in relatively healthy individuals who at the time of the study had no diseases and had no lung diseases in the past (Table II). It was found that in patients with sensitive forms of pulmonary tuberculosis, the level of elastase ranged from 35.2 to $215.1 \mathrm{nmol} / \mathrm{min} \cdot \mathrm{ml}$, on average it was $110.1 \pm 11.8$ $\mathrm{nmol} / \mathrm{min} \bullet \mathrm{ml}$. The level of NE in patients of subgroup 1a $(110.1 \pm 11.8)$ exceeded its value in healthy individuals by 1.5 times, which is significantly higher than its values in healthy individuals $(\mathrm{p}<0.01)$. In patients with multidrug-resistant tuberculosis (subgroup 1b), the level of elastase ranged from 34.6 to $163.1 \mathrm{nmol} / \mathrm{min} \bullet \mathrm{ml}$ with an average value of $78.4 \pm 9.2(\mathrm{p}<0.05)$. The level of NE in patients of subgroup $1 \mathrm{~b}$ exceeded its value in healthy individuals by 1.1 times, but this difference was insignificant ( $\mathrm{p}>0.05)$.

At the same time, the level of elastase in patients sensitive to antibacterial drugs pulmonary tuberculosis exceeded its level in patients with multi-resistant forms of tuberculosis by $31.7 \mathrm{nmol} / \mathrm{min} \bullet \mathrm{ml}$, or 1.4 times $(\mathrm{p}<0.05)$.

In the second group, all 13 studied patients sensitive to antibacterial drugs pleurisy had a level of neutrophil elastase, which ranged from $144.7-350.5 \mathrm{nmol} / \mathrm{min}$ • $\mathrm{ml}$ (Table III). The mean value of elastasis was $253.2 \pm 16.7$ $\mathrm{nmol} / \mathrm{min} \bullet \mathrm{ml}$. In the case of the control group, the level of elastase were 3.4 times larger. Compared with the first (PTB) group, the level of elastase was 2.2 times higher than in subgroup 1a (pulmonary tuberculosis is sensitive to antibiotic therapy). That is, the level of neutrophilic elastase in patients with tuberculous pleurisy was significantly higher than in patients with pulmonary tuberculosis $(\mathrm{p}<0.01)$ and more than in individuals from the control group $(\mathrm{p}<0.05)$.

Among the patients of the third group, who were diagnosed with sensitive tuberculosis (subgroup 3a), the level of NE fluctuated within $62.5-309.8 \mathrm{nmol} / \mathrm{min} \bullet \mathrm{ml}$, on average it was $176.9 \pm 17.4 \mathrm{nmol} / \mathrm{min} \bullet \mathrm{ml}$, then there is 2.4 times more than in the control group $(\mathrm{p}<0.01)$. Among the subjects of this group, in which there was resistant tuberculosis to antibacterial drugs (subgroup $3 \mathrm{~b}$ ), the level of NE was in the range of $62.5-291.4 \mathrm{nmol} / \mathrm{min} \bullet \mathrm{ml}$, ie the average value of the indicator was not at the level of $173.8 \pm 26.9 \mathrm{nmol} / \mathrm{min} \bullet \mathrm{ml}$, which is 2.3 times more than in the control group $(\mathrm{p}<0,01)$. The average level of NE in subgroup 3a was $176.9 \mathrm{nmol} / \mathrm{min} \bullet \mathrm{ml}$ practically did not differ from the level of NE in subgroup $3 b-173.8 \mathrm{nmol} /$ $\min \bullet \mathrm{ml}(\mathrm{p}>0.05)-($ Table IV). 
We compared the level of NE in patients of different groups with susceptible tuberculosis (Table V). In persons of subgroup 3a the level of NE was 1.6 times higher than in patients of subgroup $1 \mathrm{a}-110.1 \mathrm{nmol} / \mathrm{min} \bullet \mathrm{ml}(\mathrm{p}<0.01)$ and 2.3 times less than in patients of group II $-253.2 \mathrm{nmol} /$ $\min \bullet \mathrm{ml}(\mathrm{p}<0.01)$.

We also compared the level of elastase in multidrug-resistant tuberculosis in patients with PTB and PTB - PLTB (Table V). The level of NE in subgroup 3b differed significantly from subgroup $1 b$. Thus, in subgroup $1 b$ of the subjects the level of NE was $85.3 \mathrm{nmol} / \mathrm{min} \bullet \mathrm{ml}$, and in subgroup $3 \mathrm{~b}$ was $173.8 \mathrm{nmol} / \mathrm{min} \bullet \mathrm{ml}$, ie it was 2 times higher $(\mathrm{p}<0.01)$.

The results show that in patients with pulmonary and pleural tuberculosis, sensitive to antibacterial therapy, the level of elastase significantly exceeded in those who did not have at the time of examination and in the past lung and pleural diseases. In pulmonary tuberculosis it was 1.6 times higher, and in patients with tuberculous pleurisy 3.4 times higher than in the control group. At the same time, when combining pulmonary tuberculosis with pleural, the level of elastase was 2.4 times higher than in the control group. Thus, the most active proteolytic system was in isolated pleural tuberculosis, and the pulmonary process significantly reduced this activity. In pulmonary tuberculosis, the activity of the proteolytic system was even lower.

Resistance of Mycobacterium tuberculosis in specific patients (multidrug-resistant tuberculosis) affected proteolytic activity by inhibition in patients of all groups (Table V).

\section{CONLUSIONS}

1) The level of neutrophil elastase in patients with tuberculous pleurisy is 2.2 times higher than in patients with pulmonary tuberculosis $(110.1 \mathrm{nmol} / \mathrm{min} \bullet \mathrm{ml})$ and higher than in combined pulmonary and pleural tuberculosis $(176.9 \mathrm{nmol} / \mathrm{min} \bullet \mathrm{ml}) 1.4$ times $(\mathrm{p}<0.01)$. This can be explained on the one hand by the greater "use" of elastase in pulmonary forms of tuberculosis, and on the other - increased production of it in pleural tuberculosis, which contributes to increased "permeability" of the pleural leaves.

2) The level of neutrophil elastase in the combined process (lungs and pleura) is 2.4 times higher than in the control group, but almost no different from sensitive forms of pulmonary tuberculosis.

3) With sensitive joint tuberculosis (lungs and pleura), the level of NE was 1.5 times higher than in patients of subgroup $1 \mathrm{a}(\mathrm{p}<0.01)$ and 1.4 times less than in patients with tuberculous pleurisy $(\mathrm{p}<0.01)$.

4) In multidrug-resistant pulmonary tuberculosis, the level of NE ( $85.3 \mathrm{nmol} / \mathrm{min} \bullet \mathrm{ml})$ was 2 times lower than in combined tuberculosis (lungs and pleura) $(\mathrm{p}<0.01)$. In resistant forms of tuberculosis, the immune response, in the form of activity of the proteolytic system, is lower than in sensitive forms, which can be associated with both the weakness of the body as a whole and the aggressiveness of the pathogen.

\section{REFERENCES}

1. Terleeva J.S., Goncharova M.I., Kuzin I.V. at al. Bariery likuvannia tuberkulozu v Ukraini [Barriers to TB treatment in Ukraine]. Tuberkuloz, lehenevi khvoroby, VIL-infektsiia. 2020;3(42):7-16. (UA).

2. State Institution «Public Health Center of the Ministry of Health of Ukraine». Access mode: https://www.phc.org.ua/kontrol-zakhvoryuvan/ tuberkuloz/statistika-z-tb/analitichno-statistichni-materiali-z-tb. (UA).

3. Makinskij A. I., Spirina A. Ja., Docenko V. L. at al. Sposob opredelenija aktivnosti tuberkuleznyh izmenenij v legkih [Method for determining the activity of tuberculous changes in the lungs]. Patent №2161313. Moscow Medical Academy by I.M. Sechenov. Application filing: 07.10.1999, patent publication: 27.12.2000. (Ru).

4. Duzhiy I.D., Oleshchenko G.P., Gresko I.Ya. at al. Patent of Ukraine № 114430 Sposib poperednoi veryfikatsii syndromu plevralnoho vypotu [Method of preliminary verification of pleural effusion syndrome]. Application filing: 29.08.16; patent publication: 10.03.17 (UA).

The work is carried out within the framework of the research work «Features of hormonal status and proteolytic system in patients with various forms of pulmonary tuberculosis» (state registration number 0118U007020).

\section{ORCID and contributionship:}

Ihor D. Duzhyi: 0000-0002-4995-0096 A,E,F

Halyna P. Oleshchenko: 0000-0002-9188-490X ${ }^{B, C, D}$

Ivan A. Hnatenko: 0000-0002-7739-738X ${ }^{B, D}$

Stanislav O. Holubnychyi: 0000-0002-4965-0114 ${ }^{B, C}$

\section{Conflict of interest:}

The Authors declare no conflict of interest.

\section{CORRESPONDING AUTHOR Halyna P. Oleshchenko \\ Sumy State University \\ 2, Rymskogo-Korsakova st., 40030, Sumy, Ukraine \\ tel: +380997463325 \\ e-mail: g.oleschenko@med.sumdu.edu.ua}

Received: 15.07.2020.

Accepted: 20.12 .2020

A - Work concept and design, B - Data collection and analysis, C - Responsibility for statistical analysis, D-Writing the article, $\mathbf{E}$-Critical review, $\mathbf{F}$ - Final approval of the article 